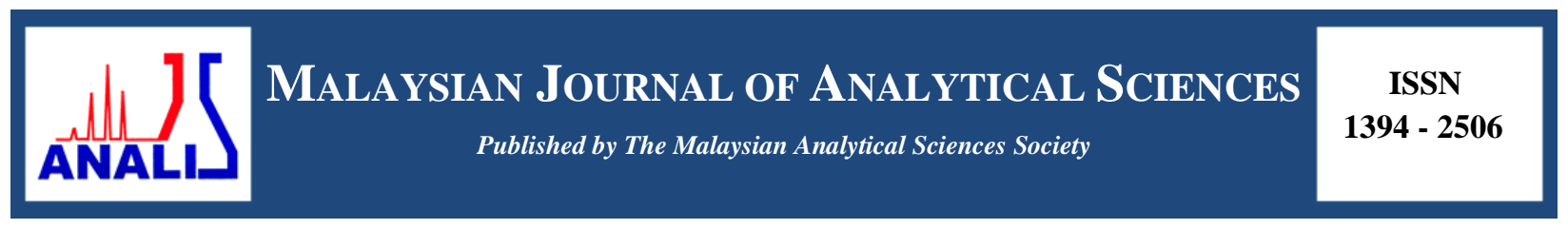

\title{
THERMAL PROPERTIES AND CONDUCTIVITY OF NAFION-ZIRCONIA COMPOSITE MEMBRANE
}

\section{(Sifat Terma dan Konduktiviti Membran Komposit Nafion-Zirkonia)}

\author{
Siti Rahmah Mokhtaruddin ${ }^{1,2}$, Abu Bakar Mohamad ${ }^{1,2}$, Kee Shyuan Loh ${ }^{1}$, Abdul Amir Hasan Kadhum ${ }^{1,2}$ \\ ${ }^{1}$ Fuel Cell Institute \\ ${ }^{2}$ Department of Chemical and Process Engineering, Faculty of Engineering and Built Environment \\ Universiti Kebangsaan Malaysia, 43600 UKM Bangi, Selangor, Malaysia \\ *Corresponding author: drab@ukm.edu.my
}

Received: 5 February 2016; Accepted: 22 April 2016

\begin{abstract}
The application of composite membranes for high temperature polymer electrolyte membrane fuel cell has attracted interests. Nafion-metal dioxide composite membranes are considered among the research niche. In this study, Nafion membranes and Nafion-zirconia composite membranes with 1, 3 and 5 wt. \% of hydrous zirconia were prepared accordingly. All membranes were characterized by quantitative analysis techniques such as thermogravimetry analyse, diffraction scanning calorimetry and Fourier transform infrared. All composite membranes showed high glass transition temperatures and improved water retention properties, compared to the Nafion membrane. The composite membrane with 3 wt. \% of zirconia showed the highest thermal resistance at $90^{\circ} \mathrm{C}$.
\end{abstract}

Keywords: high temperature PEM, glass transition temperature, conductivity, composite membrane, Nafion-zirconia

\begin{abstract}
Abstrak
Penggunaan membran komposit dalam operasi sel bahanapi membran penukar proton pada suhu tinggi semakin mendapat perhatian pengkaji. Membran komposit Nafion-logam dioksida adalah antara bidang kajian dalam kumpulan ini. Bagi kajian ini, membran Nafion dan membran komposit Nafion-zirkonia dengan 1, 3, dan 5 wt. \% telah disediakan. Kesemua membran dicirikan menggunakan teknik analisis kuantitatif seperti analisis termogravimetri, kalorimetri imbasan kerbedaan dan Fourier inframerah. Kesemua membran komposit mempunyai suhu peralihan kaca yang tinggi dan keupayaan penahanan air yang lebih baik berbanding membran Nafion. Membran komposit dengan 3 wt. \% zirkonia menunjukkan ketahanan suhu tinggi pada suhu operasi $90^{\circ} \mathrm{C}$.
\end{abstract}

Kata kunci: PEM suhu tinggi, suhu peralihan kaca, konduktiviti, membran komposit, Nafion-zirkonia

\section{Introduction}

Fuel cells are electrochemical devices which convert the energy from the reaction of fuel and oxygen into electric energy continuously with water and $\mathrm{CO}_{2}$ as the byproducts [1]. Polymer electrolyte membrane fuel cell (PEMFC) is one of the fuel cell types, for temperature ranging from $60-100{ }^{\circ} \mathrm{C}$. Nafion membranes are the most commonly used polymer electrolytes in PEMFC application as it has excellent chemical, mechanical and electrochemical properties as well as high proton conductivity at ambient temperature and high humidity condition. This waterbased electrolyte needs to be kept in a hydrated condition for the best performance and a maximum conductivity of $0.083 \mathrm{~S} / \mathrm{cm}$ at $100 \%$ relative humidity $(\mathrm{RH})[2]$. 
However, the membrane tends to shrink at low humidity and swells under excess water conditions due to its molecular structure. The ionic groups form clusters of $2-4 \mathrm{~nm}$ in diameter, which are connected by narrow channels; the size of these clusters is proportional to the water level in the membrane, which can explain the shrinkswell behavior of the polymer [3]. Therefore, developing membranes with good stability for both thermal and mechanical properties is desirable. Many methods have been developed to produce composite membranes, including incorporating hygroscopic metal oxides such as $\mathrm{SiO}_{2}$ [4], $\mathrm{TiO}_{2}$ [5] and $\mathrm{ZrO}_{2}$ [6] into the Nafion polymer structure. Incorporating a hydrophilic, inorganic material into the perfluorinated polymer is an alternative way to increase the binding energy of water [7]. The membrane strength and performance increased, as the organic polymer formed strong interaction with the inorganic component having large specific area [8].

In this study, a series of Nafion- $\mathrm{ZrO}_{2}$ composite membranes with 1,3 and 5 wt. $\%$ of hydrous zirconia loading were prepared with the purpose of increasing the thermal resistance of membrane, thus increasing the proton conductivity of the membrane. The hygroscopic property of zirconia was expected to improve the thermal strength of the membrane by increasing the glass transition temperature.

\section{Materials}

\section{Materials and Methods}

The 5 wt. \% Nafion solution (EW 1100) and Nafion 115 were purchased from DuPont, USA. Zirconium (IV) oxychloride octahydrate $\left(\mathrm{ZrOCl}_{2} \cdot 8 \mathrm{H}_{2} \mathrm{O}\right)$, ammonium solution $\left(\mathrm{NH}_{4} \mathrm{OH}\right)$, dimethylformamide (DMF), sulfuric acid $\left(\mathrm{H}_{2} \mathrm{SO}_{4}, 98 \%\right)$ and hydrogen peroxide $\left(\mathrm{H}_{2} \mathrm{O}_{2}, 30 \%\right)$ were all purchased from Aldrich. Deionized water was used as the solvent in all experiments.

\section{Preparation of the Nafion- $\mathrm{ZrO}_{2}$ composite membrane}

Nafion solution was evaporated at room temperature to obtain solid Nafion. The solid Nafion was then dissolved in DMF and stirred for two hours. Meanwhile, the hydrous zirconia was prepared via film casting process according to the method proposed by Chuah et al [9]. $\mathrm{ZrOCl}_{2} \cdot 8 \mathrm{H}_{2} \mathrm{O}$ was dissolved in distilled water. Dilute aqueous ammonia was added drop-wise to the solution with vigorous stirring until the $\mathrm{pH}$ of the solution reached 10 . The obtained precipitate was washed with distilled water several times to remove the chloride ions before being oven-dried at $100^{\circ} \mathrm{C}$ for 12 hours. Matrices of 1,3 and 5 wt $\%$ of Nafion- $\mathrm{ZrO}_{2}$ were mixed in a DMF solution. Subsequently, the mixture was casted onto a container and heated at $80^{\circ} \mathrm{C}$ for 2 hours, before the temperature was increased to $110^{\circ} \mathrm{C}$ for six hours to enhance the polymer strength and remove excess solvent. After that, the recast composite membrane was detached from the container and washed with a $3 \mathrm{wt} \% \mathrm{H}_{2} \mathrm{O}_{2}$ and $0.5 \mathrm{M} \mathrm{H}_{2} \mathrm{SO}_{4}$ solution. These samples were labeled as NZ01, NZ03 and NZ05 according to the loading of $1 \mathrm{wt} \%, 3 \mathrm{wt} \%$ and $5 \mathrm{wt} \%$ of hydrous zirconia, respectively. A similar method was used to prepare the recast Nafion.

\section{Characterization of the Nafion- $\mathrm{ZrO}_{2}$ composite membrane}

The infra-red spectra of the composite membranes (NZ01, NZ03 and NZ05) were recorded to detect the functional groups chemical change in the polymer as compared to pure Nafion membrane. A Thermo Fisher Scientific FTIR (Nicolet 6700) spectrophotometer was used in the analyses.

The DSC spectra of the prepared composite membranes were obtained using a DSC 1 Star System (Mettler Toledo). Membrane samples were cut and weighed to $0.25 \mathrm{~g}$ in an aluminum crucible. Measurements were performed over the temperature range of $30-300{ }^{\circ} \mathrm{C}$ with a heating rate of $20^{\circ} \mathrm{C} / \mathrm{min}$ under nitrogen gas.

The ionic conductivity of the membranes was measured with a potentiostat (Autolab, PGSTAT 128N) in the frequency range between $1 \mathrm{mHz}$ and $100 \mathrm{kHz}$. The membrane samples were immersed for 30 minutes in de-ionized water at the desired temperature before being placed on electrode cells for measurements. The measurement was carried out at room temperature and at $90{ }^{\circ} \mathrm{C}$ in order to study the effect of operating temperature and compositions of the inorganic compound embedded in the polymer matrix towards conductivity at $90{ }^{\circ} \mathrm{C}$. The graph of the negative imaginary impedance versus the real impedance was plotted for each set of data. The bulk impedance $R_{b}$ of the samples was determined from the curve and thus, the ionic conductivity, $\sigma$, was calculated using Equation 1.

$$
\sigma=t /\left(R_{b} * A\right)
$$


where, $t$ is the sample thickness $(\mathrm{cm}), A$ is the effective contact area of the film and the electrode $\left(\mathrm{cm}^{2}\right)$ and $\mathrm{R}_{\mathrm{b}}$ is the bulk resistance $(\Omega)$.

\section{Structure analysis}

\section{Results and Discussion}

Figure 1 shows the FTIR spectra of recast Nafion; NZ01, NZ03, NZ05 composite membranes; and hydrous zirconia. The peaks at $3455.03-3428 \mathrm{~cm}^{-1}$ are assigned to the bending vibrations of water molecules and the $\mathrm{OH}$ stretching mode of the adsorbed water [10]. It is observed that the broad peak of the $-\mathrm{OH}$ peak increases with the addition of the zirconia composition. The peaks at $1198.28 \mathrm{~cm}^{-1}, 1198.25 \mathrm{~cm}^{-1}$ and $1198.32 \mathrm{~cm}^{-1}$ are attributed to the $-\mathrm{CF}_{2}-\mathrm{CF}_{2^{-}}$vibration, as reported by Zhai et al. [11]. The $-\mathrm{SO}_{3^{-}}$peaks appear at $1059.26 \mathrm{~cm}^{-1}, 1058.19 \mathrm{~cm}^{-1}$ and $1055.21 \mathrm{~cm}^{-1}$. The IR spectra of NZ01, NZ03 and NZ05 are similar to that of recast Nafion, except for the appearance of a small peak near $1500 \mathrm{~cm}^{-1}$, indicating the existence of hydrous zirconia molecules in the composite membranes. The peak that appears around $1530.49-1520.22 \mathrm{~cm}^{-1}$ indicates the $\mathrm{Zr}-\mathrm{OH}$ bending vibrations. Peaks at $514.28 \mathrm{~cm}^{-1}$ and $513.72 \mathrm{~cm}^{-1}$ show the $\mathrm{Zr}-\mathrm{O}$ vibrations, which are overlapped by the transmittance peaks of the Nafion [12]. As mentioned by Pan et al., the overlapping peaks suggest that the addition of zirconia does not affect the crystallinity or the molecular structure of the Nafion membrane [6].

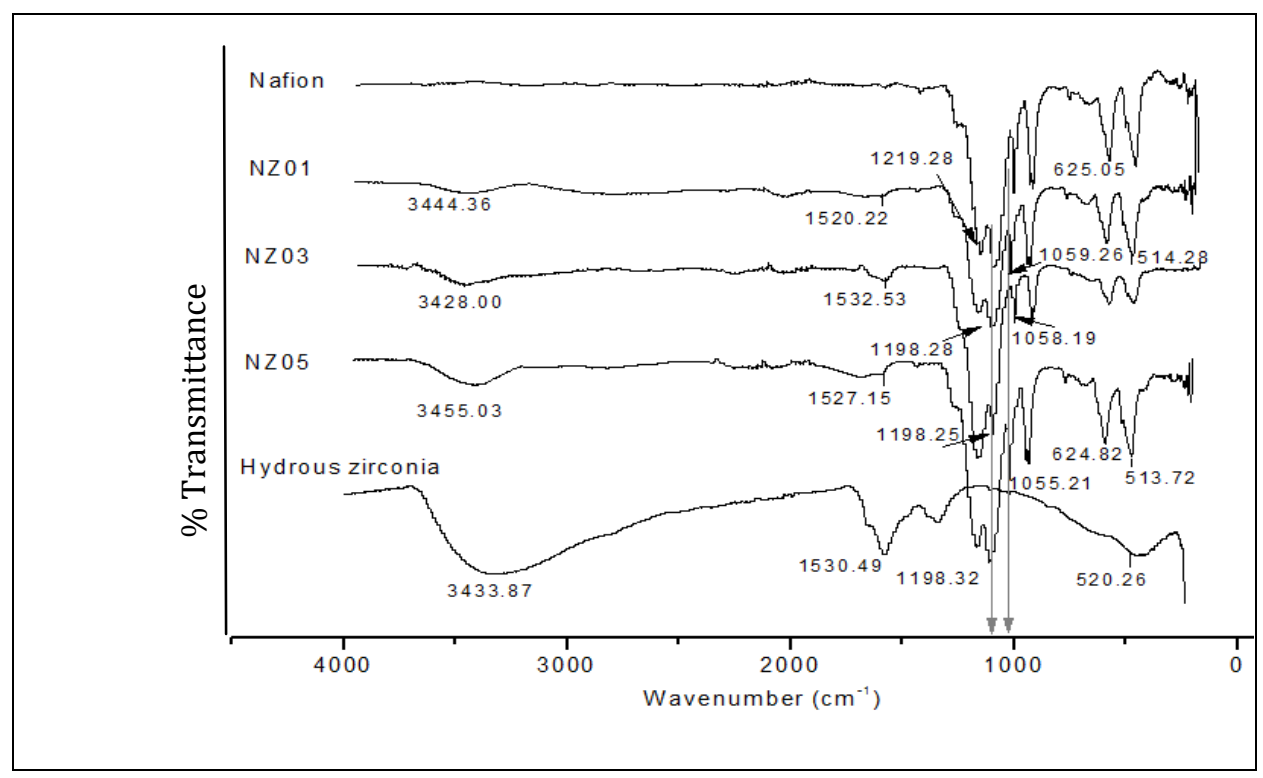

Figure 1. FTIR spectra of Nafion and Nafion- $\mathrm{ZrO}_{2}$ composite membranes

\section{Thermal properties}

The results obtained from thermal gravimetric analysis (TGA) is shown in Figure 2. The TGA curves show a three step degradation, which is the loss of physically and chemically bound water (below $200{ }^{\circ} \mathrm{C}$ ), the decomposition of sulfonic acid groups or desulfonation $\left(250-400{ }^{\circ} \mathrm{C}\right)$ and main chain degradation $\left(400-800^{\circ} \mathrm{C}\right)$ [13]. As expected, recast Nafion degrades faster than the composite membranes in all three degradation steps.

The magnified portion of the graph shows the first part of the degradation. Low of mass loss $(<6 \%)$ is shown for the composite membranes at this temperature range. The degradation of the Nafion membrane was caused by the breakage of the perfluorinated backbone and the side-chains in the membrane. The desulfonation of the membrane starts at approximately $280{ }^{\circ} \mathrm{C}$ for the recast Nafion membrane, whereas it begins higher for the composite membranes, at the temperatures of $300{ }^{\circ} \mathrm{C}$ for NZ01 and NZ03, $280{ }^{\circ} \mathrm{C}$ for NZ05, which indicates the breaking of 
C-S bonds. NZ05 has the lowest desulfonation temperature among the composite membranes, which is similar to the recast Nafion.

For the third step of the degradation, it is clearly seen that the Nafion decomposes at a lower temperature than the composite membranes. Iwai and Yamanishi [14] have reported that cations with larger ionic radii show higher thermal stability when reacted with Nafion and Zirconia is a metal oxide with large molecular radius. Therefore, the composite membranes have higher thermal retention as a higher temperature is needed to activate the energy barrier and break the bond.

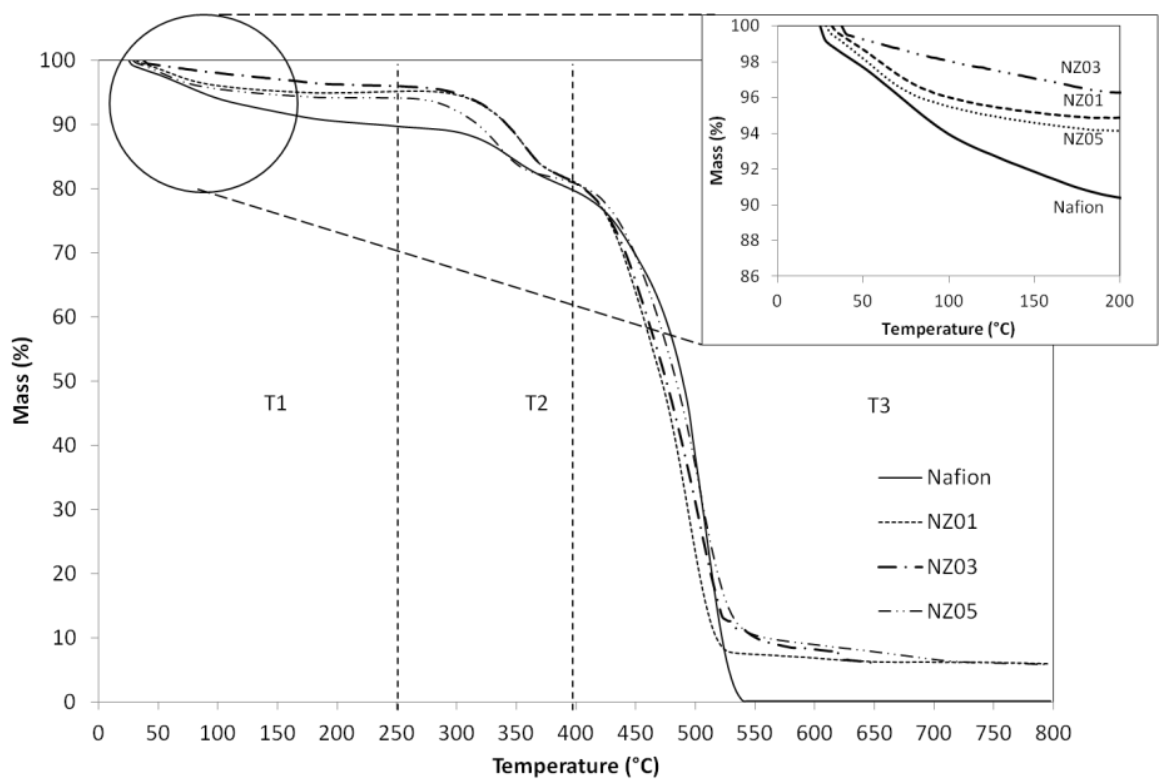

Figure 2. TGA curves for Nafion and composite membranes. T1: Water loss, T2: desulfonation, T3: main chain degradation.

Figure 3 shows that an endothermic peak appears at approximately $70-90{ }^{\circ} \mathrm{C}$, which increases up to 3 wt. $\%$ of hydrous zirconia content, indicating the enhanced water retention. These broad peaks (ranging from $50-140{ }^{\circ} \mathrm{C}$ ) caused by the structural change in the membrane cluster as shown in the FTIR spectrum. The composite membranes show different behavior than Nafion membrane as temperature increases. This observation is consistent with the report by Sacca et al [2], where zirconia functions well as a hygroscopic compound in improving the water content in the membrane, although the pattern shows a decrease for NZ05. At the desulfonation phase, the recast Nafion degraded slower than the Nafion membrane, as they have amorphous zirconia to resist the degradation. A broad exothermic peak appears at approximately $350{ }^{\circ} \mathrm{C}$ for all composite membranes, which is attributed to the dehydroxylation of the hydrous zirconia with increasing temperature. The exothermic event is then followed by another weight loss due to main chain degradation. The exothermic peak with weight change is assigned to the releasing of hydroxyl groups at a high temperature, resulting in the formation and crystallization of the amorphous zirconia [15]. Another two peaks of crystallization appear at approximately $450{ }^{\circ} \mathrm{C}$ and $550{ }^{\circ} \mathrm{C}$, indicating another phase change in the hydrous zirconia.

From Figure 3, it is seen that Nafion had loss almost $10 \%$ of mass at $300{ }^{\circ} \mathrm{C}$ but the NZ01 and NZ03 composite membranes had retain more than $95 \%$ of their weight while NZ05 had $8 \%$ mass loss at the same temperature. Above $300{ }^{\circ} \mathrm{C}$, all membranes decompose rapidly as the membranes starts losing their sulfonyl chain in the Nafion matrix. However, the temperature shifted for the composite membranes, due to the nature of the hygroscopic inorganic component; increasing water content in the composite membrane [16]. Thermal degradation of Nafion 
membrane occurs at $308{ }^{\circ} \mathrm{C}$; whereas the degradation temperature shifted to $333{ }^{\circ} \mathrm{C}$ for both NZ01 and NZ03, and at $317^{\circ} \mathrm{C}$ for NZ05. Shao has reported that the increment of degradation temperature is due to the addition of metal oxide (such as $\mathrm{SiO}_{2}, \mathrm{TiO}_{2}, \mathrm{ZrO}_{2}$ ) into the Nafion matrix as the inorganic compound is temperature tolerant filler [17].

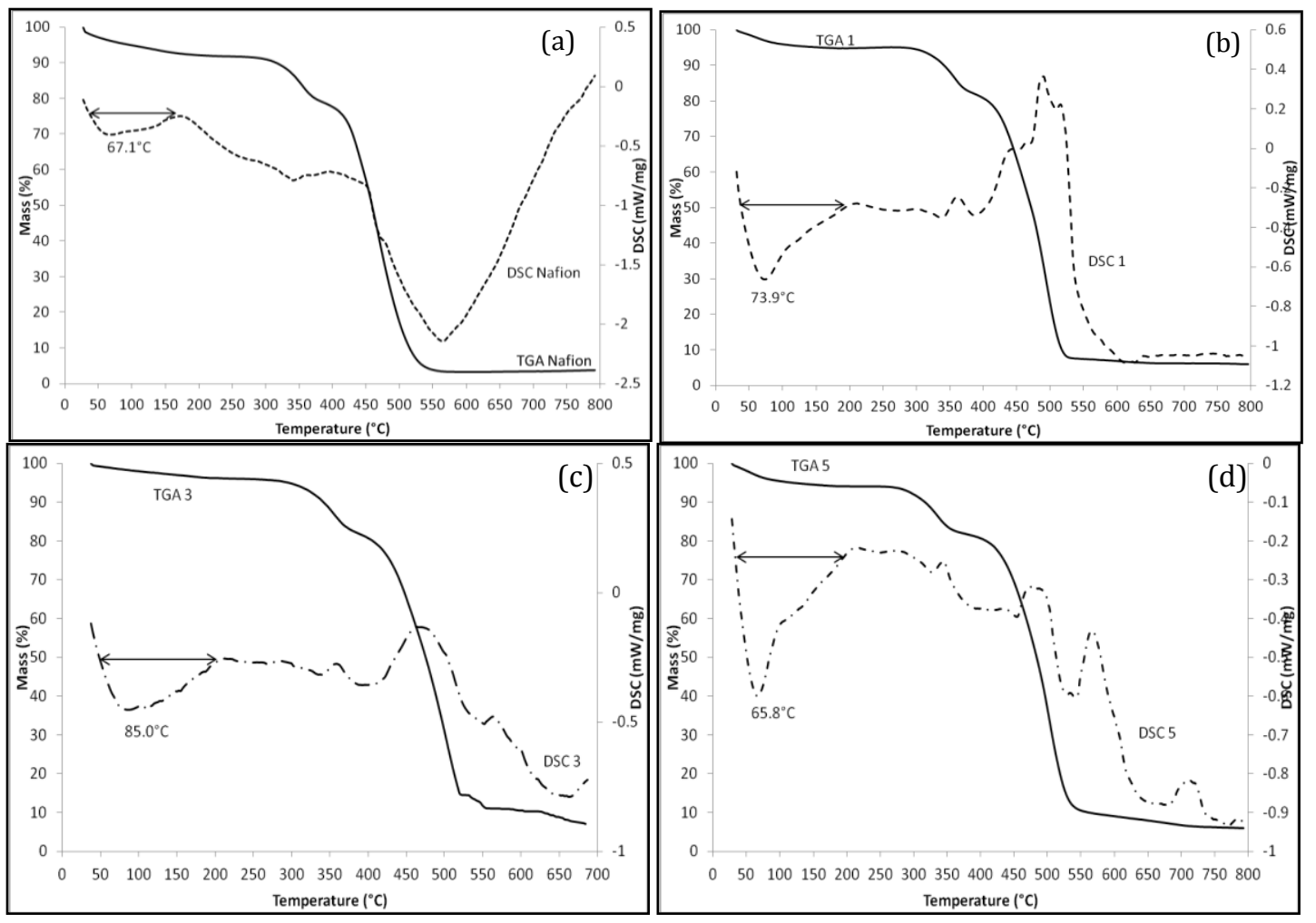

Figure 3. TG and DSC curves of composite membranes, taken at $10^{\circ} \mathrm{C} / \mathrm{min}$, under $\mathrm{N}_{2}$, for (a) Nafion, (b) NZ01, (c) NZ03, (d) NZ05.

As for the glass transition temperature $\left(\mathrm{T}_{\mathrm{g}}\right)$, another test was conducted using differential scanning calorimetry (DSC). The related results are shown in Table 1, increased in the sequence of: Recast Nafion $<$ NZ05 $<$ NZ01 < NZ03. It is seen that the $\mathrm{T}_{\mathrm{g}}$ value of Nafion membrane is observed at $117.73{ }^{\circ} \mathrm{C}$, which is lower than the $\mathrm{T}_{\mathrm{g}}$ of the composite membranes. Whilst, NZ03 has the highest $\mathrm{T}_{\mathrm{g}}=171.50{ }^{\circ} \mathrm{C}$, indicating the strength of the membrane to resist high temperature is improved. Incorporation of the amorphous zirconia particles into Nafion polymer matrix would improve the thermal stability and increase the $\mathrm{T}_{\mathrm{g}}$ [18]. The occupied inorganic particles resulting on more energy needed for starting segmental motions, which would increase the $T_{g}$ value. However, the $T_{g}$ value decreases for NZ05, despite having the same thickness with NZ03 composite membrane. Probably, the presence of excessive inorganic particles has weakened its structure by forming a brittle membrane [2].

\section{Membrane conductivity}

Figure 4 shows the typical impedance curves of four different membranes. Fundamentally, all depicted spectra consist of two arcs, one each for low and high frequency. The basic circuit of a circle is R(RQ), as depicted below the plotted graph. The graph shows the increasing diameter of the arcs within the composition, except for NZ05 which represent increase conductivity. 
Siti Rahmah et al: THERMAL PROPERTIES AND CONDUCTIVITY OF NAFION-ZIRCONIA COMPOSITE MEMBRANE

Table 1. Thermal properties of recast Nafion and composite membranes

\begin{tabular}{lccc}
\hline Membrane & $\begin{array}{c}\text { Thickness } \\
(\boldsymbol{\mu m})\end{array}$ & $\begin{array}{c}\text { Residue } \\
(\boldsymbol{\%})\end{array}$ & $\begin{array}{c}\text { Glass transition temperature } \\
(\mathbf{T g})\end{array}$ \\
\hline Nafion & 127.00 & 3.64 & 117.73 \\
NZ01 & 107.07 & 6.01 & 139.62 \\
NZ03 & 121.47 & 6.02 & 145.28 \\
NZ05 & 122.97 & 5.89 & 141.33 \\
\hline
\end{tabular}
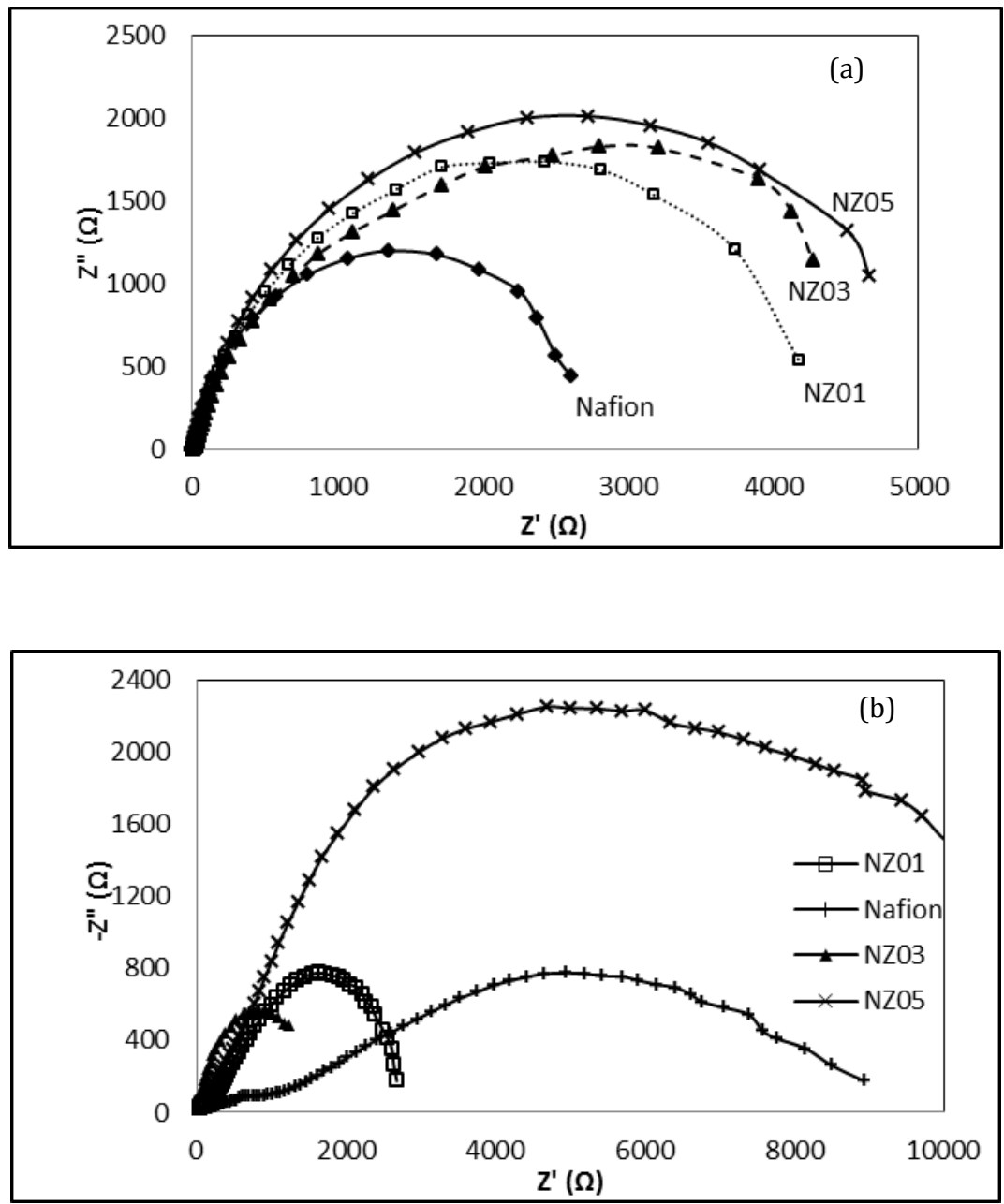

Figure 4. Impedance curves of Nafion and the composite membranes (a) room temperature and (b) at $90^{\circ} \mathrm{C}$

The equivalent circuit that is presented in Figure 4 provides a good fitting for these responses. Each circuit consists of two sets of resistor-capacitor pairs. The calculated conductivity of the Nafion membrane at room temperature is $8.32 \times 10^{-3} \mathrm{~S} / \mathrm{cm}$. From the obtained data, the ionic conductivity of the composite membranes ranges from $1.41 \times 10^{-2}$ 
$\mathrm{S} / \mathrm{cm}$ to $1.62 \times 10^{-2} \mathrm{~S} / \mathrm{cm}$. These values increase proportionally with the zirconia composition, which is consistent to the results reported by Uma [19].

Impedance curves for the Nafion and the composite membranes at $90{ }^{\circ} \mathrm{C}$ were shown in Figure $4 \mathrm{~b}$. The circle diameters for NZ01 and NZ03 are smaller than the Nafion membrane and the NZ05 composite membrane. A decreased diameter results in higher conductivity. Compared to the value for room temperature measurements, NZ01 and NZ03 at $90^{\circ} \mathrm{C}$ have circles in smaller diameter, indicating good conduction of the membranes. As the temperature increases, the conductivity is also increases [20]. The calculated conductivity increases from 0.014 to $0.042 \mathrm{~S} / \mathrm{cm}$ for NZ03 and increased from 0.014 to $0.022 \mathrm{~S} / \mathrm{cm}$ for NZ01. On the contrary, the conductivity is decreased for the Nafion and the NZ05 composite membrane. For the commercial Nafion, the plotted arcs have the same equivalent circuit (two arcs) as at room temperature but with larger diameter, resulting in a lower conductivity. This effect is caused by the weak thermal resistance of Nafion, as a result of which the membrane starts to shrink at a temperature near $100^{\circ} \mathrm{C}[21]$.

\section{Conclusion}

In this study, Nafion- $\mathrm{ZrO}_{2}$ composite membranes were prepared through film casting process and characterized for their structure, morphology, thermal stability and conductivity. The Nafion membrane exhibited lower conductivity than the composite membranes at room temperature under fully hydrated conditions. Despite an increase in temperature, the conductivity of the composite membranes improves. This effect is due to the hygroscopic properties of hydrous zirconia, which has an optimal content of $3 \mathrm{wt}$. \%. Whenever excess hydrous zirconia is used, the conductivity decreases and it affects the in situ performance of the membrane in the membrane electrode assembly (MEA) due to the increase in the particle size. Through understanding that the composite membrane has an improved water uptake and conductivity at room temperature and at $90{ }^{\circ} \mathrm{C}$, further investigation will be conducted in the future to explore the effect of hydrous zirconia on the performance at moderate temperature $\left(100{ }^{\circ} \mathrm{C}\right)$.

\section{Acknowledgement}

The authors gratefully thank the financial support from the Universiti Kebangsaan Malaysia (UKM) through research grants UKM-GUP-BTT-07-30-188 and UKM-AP-TK-05-2009. The National Science Fellowship awarded to Siti Rahmah Mokhtaruddin is also acknowledged.

\section{References}

1. Raharjo, J., Muchtar, A., Daud, W. R. W., Muhamad, N. and Majlan, E. H. (2012). Pencirian fizikal dan terma komposit seramik elektrolit SDC-(Li/Na) ${ }_{2} \mathrm{CO}_{3}$. Sains Malaysiana, 41(1): 95 - 102.

2. Saccà, A., Gatto, I., Carbone, A., Pedicini, R. and Passalacqua, E. (2006). ZrO2-Nafion composite membranes for polymer electrolyte fuel cells (PEFCs) at intermediate temperature. Journal of Power Sources, 163(1): 47 51.

3. Ramani, V., Kunz, H. R., and Fenton, J. M. (2005). Stabilized heteropolyacid/Nafion® composite membranes for elevated temperature/low relative humidity PEFC operation. Electrochimica Acta, 50(5): 1181 - 1187.

4. Dresch, M. A., Isidoro, R. A., Linardi, M., Rey, J. F. Q., Fonseca, F. C. and Santiago, E. I. (2013). Influence of sol-gel media on the properties of Nafion- $\mathrm{SiO}_{2}$ hybrid electrolytes for high performance proton exchange membrane fuel cells operating at high temperature and low humidity. Electrochimica Acta, 94(0): 353 - 359 .

5. Zhengbang, W., Tang, H. and Pan, M. (2011). Self-assembly of durable Nafion/ $\mathrm{TiO}_{2}$ nanowire electrolyte membranes for elevated-temperature PEM fuel cells. Journal of Membrane Science, 369(1-2): 250 - 257.

6. Pan, J., Zhang, H., Chen, W. and Mu, P. (2010). Nafion-zirconia nanocomposite membranes formed via in situ sol-gel process. International Journal of Hydrogen Energy, 35(7): 2796 - 2801.

7. Hammami, R., Ahamed, Z., Charradi, K., Beji, Z., Ben Assaker, I., Ben Naceur, J., Auvity, B., Squadrito, G. and Chtourou, R. (2013). Elaboration and characterization of hybrid polymer electrolytes $\mathrm{Nafion}-\mathrm{TiO}_{2}$ for PEMFCs. International Journal of Hydrogen Energy, 38(26): 11583 - 11590.

8. Thiam, H. S., Daud, W. R. W., Kamarudin, S. K., Mohamad, A. B., Kadhum, A. A. H., Loh, K. S. and Majlan, E. H. (2013). Nafion/ $\mathrm{Pd}-\mathrm{SiO}_{2}$ nanofiber composite membranes for direct methanol fuel cell applications. International Journal of Hydrogen Energy, 38(22): 9474 - 9483. 
9. Chuah, G. K., Jaenicke, S., Cheong, S. A., and Chan, K. S. (1996). The influence of preparation conditions on the surface area of zirconia. Applied Catalysis A: General 145(1-2): 267 - 284.

10. Yang H. N., Lee D. C., Park S. H. and Kim W. J. (2013). Preparation of Nafion/various Pt-containing $\mathrm{SiO}_{2}$ composite membranes sulfonated via different sources of sulfonic group and their application in selfhumidifying PEMFC. Journal of Membrane Science, 443: 210 - 218.

11. Zhai, Y., Zhang, H., Hu. J. and Yi, B. (2006). Preparation and characterization of sulfated zirconia $\left(\mathrm{SO}_{4}{ }^{2-} / \mathrm{ZrO}_{2}\right) / \mathrm{Nafion}$ composite membranes for PEMFC operation at high temperature/low humidity. Journal of Membrane Science, 280(1-2): 148 - 155.

12. Sarkar, D., Mohapatra, Deepak, Ray, S., Bhattacharyya, S., Adak, S. and Mitra, N. (2007). Synthesis and characterization of sol-gel derived $\mathrm{ZrO}_{2}$ doped $\mathrm{Al}_{2} \mathrm{O}_{3}$ nanopowder. Ceramics International, 33(7): 1275 1282.

13. Wu, C. M., Xu, T., W. and Yang, W. H. (2004). Synthesis and characterizations of new negatively charged organic-inorganic hybrid materials: effect of molecular weight of sol-gel precursor. Journal of Solid State Chemistry, 177(4-5): 1660-1666.

14. Iwai, Y. and Yamanishi, T. (2009). Thermal stability of ion-exchange Nafion N117CS membranes. Polymer Degradation and Stability, 94(4): 679 - 687.

15. Gong-Yi Guo, Yu-Li Chen and Wei-Jiang Ying. (2004). Thermal, spectroscopic and X-ray diffractional analyses of zirconium hydroxides precipitated at low $\mathrm{pH}$ values. Materials Chemistry and Physics, 84(2-3): $308-314$.

16. Yu, S., Zuo, X., Bao, R., Xu, X., Wang, J. and Xu, J. (2009). Effect of $\mathrm{SiO}_{2}$ nanoparticle addition on the characteristics of a new organic-inorganic hybrid membrane. Polymer, 50(2): $553-559$.

17. Shao, Z-G., Joghee, P. and Hsing, I-M. (2004). Preparation and characterization of hybrid Nafion-silica membrane doped with phosphotungstic acid for high temperature operation of proton exchange membrane fuel cells. Journal of Membrane Science, 229(1-2): 43 - 51.

18. Jalani, N. H., Dunn, K. and Datta, R. (2005). Synthesis and characterization of Nafion ${ }^{-} \mathrm{MO}_{2}(\mathrm{M}=\mathrm{Zr}, \mathrm{Si}, \mathrm{Ti})$ nanocomposite membranes for higher temperature PEM fuel cells. Electrochimica Acta, 51(3): 553 - 560.

19. Uma, T. and Nogami, M. (2007). Fabrication and performance of Pt/C electrodes for low temperature $\mathrm{H}_{2} / \mathrm{O}_{2}$ fuel cells. Journal of Membrane Science, 302(1-2): $102-108$.

20. Ahmad A., Isa, K. B. Md. and Osman, Z. 2011. Conductivity and structural studies of plasticized polyacrylonitrile (PAN) - lithium triflate polymer electrolyte films. Sains Malaysiana, 40 (7): 691 - 694.

21. Wang, K., McDermid, S., Li, J., Kremliakova, N., Kozak, P., Song, C., Tang, Y., Zhang, J. and Zhang, J. (2008). Preparation and performance of nano silica/Nafion composite membrane for proton exchange membrane fuel cells. Journal of Power Sources, 184(1): 99 - 103. 